\title{
Soil Fertility Evaluation of Major Cocoa Producing Areas of Cross River State, Nigeria
}

\author{
Michael A. Kekong and Utietiang L. Undie
}

\begin{abstract}
Assessment of soil textures and fertility properties of major cocoa producing areas of Cross River State of Nigeria was carried out to ascertain their suitability for cocoa production. Thirty six (36) representative soil samples were collected between November 2016 and January 2017 from 18 selected cocoa farms in Boki, Ikom and Etung and analyzed using standard laboratory procedures. Result indicated textural classes of loamy sand, sandy loam sandy clay loam, sandy clay and clay loam soils in the cocoa farms with a mean clay 30.02 percent, silt $13.49 \%$ and sand 56.43 the result of the fertility properties of the soils show means in the ranges of $\mathbf{p H}$ (5,31-5.64), EC (0.021-0.023 ds/m), OM (2.81-3.36\%)TN (0.070.09\%), AV.P (2.82-5.92 mg/kg), exch Mg (1.47-200 cmol/kg) exchange Na $(0.05-0.06 \mathrm{cmol} / \mathrm{kg})$ ECEC $(6.73-8.94 \mathrm{cmol} / \mathrm{kg}) \mathrm{BS}$ $(77.25-82.70 \%)$. In this study area base saturation, exchangeable calcium and magnesium and total nitrogen were adequate within recommended limit. Available phosphorus, potassium, organic matter electrical conductivity and effective cation exchange capacity were below the critical level. A guarded application of appropriate fertilizers in this cocoa growing area is recommended for sustainable yield of cocoa in quantity and quality.
\end{abstract}

Index Terms - cocoa farm, fertility properties, evaluation critical level, textural classes.

\section{INTRODUCTION}

Cocoa is a major agricultural export crop of Nigeria and a major employer of labour in the crop producing areas. Nigeria is the fourth largest world producer of cocoa after Cort'Ivoire, Indonesia and Ghana and the third largest exporter [1]. In Nigeria, Cross River State is the second largest producer of cocoa after Ondo [2]. Other producing states are Ogun, Akwa Ibom, Ekiti, Delta, Osun, and Oyo. Ikom, Boki and Etung local government areas are the highest producers of cocoa in Cross River State [3]. The crop responds well to regions with coordinates not more than $20^{\circ}$, North or South of the equator [4]. This area is characterized by high temperatures and rainfall. However, the performance of Nigeria's cocoa economy has not been stable. The production increased 170,000 tons in 1999 to 389,000 tons from $2000-2010$ [5]. The factors that are responsible for the fluctuating yields include climate change impact on pests and diseases incidence, poor soil management practices and use of old planting materials.

Soil fertility is one of the essential components for a sustainable agricultural system especially - tropical climates. [6] observed that tropical soils are more diversified than temperate environments due to severe changes under high temperature and heavy rainfall that prevail in the tropics. The soils also show high spatial variability in their physical and

Published on November 23, 2020.

Dr. Michael A. Kekong, Cross River University of Technology, Nigeria. (e-mail: matikekong ${ }^{@}$ gmail.com chemical properties which leads to differential soil responses. Although few studies have been carried out in these soils, which is not sufficient, analysis with climate change impacts on soil dynamics, there is need for periodic assessment of soils of these areas if cocoa production has to be sustained.

\section{MATERIALS AND Methods}

\section{A. Study Area and Sampling Technique}

The study was carried out at Ikom, Boki, and Etung local government areas selected based on the report of [2]. The coordinates of these areas were Ikom on latitude $5^{\circ} 57 \mathrm{~N}$, and longit6ude $8^{\circ} 42 \mathrm{E}$, Boki latitude $5^{\circ} 82$ and $6^{\circ} 40 \mathrm{~N}$ and longitude 850 and $900 \mathrm{E}$ while Etung is latitude $5^{\circ} 00$ and $6^{\circ} 00 \mathrm{~N}$ and longitude $8^{\circ} 00$ and $9^{\circ} 00 \mathrm{E}$, all within the rainfall belt of Nigeria. The rainfall in this cocoa growing areas is bimodal in distribution and $1200 \mathrm{~m}-3000 \mathrm{~mm}$ in density [7].The major economic activities of this areas is farming of food and cash crops including cocoa, which is the major cash crop.

\section{B. Sampling Design and Soil Sampling}

From each local government areas, three cocoa growing communities were randomly selected. In each cocoa growing community two farms were randomly selected making a total of 18 cocoa farms. The soil samples were taken from November to December in 2016.

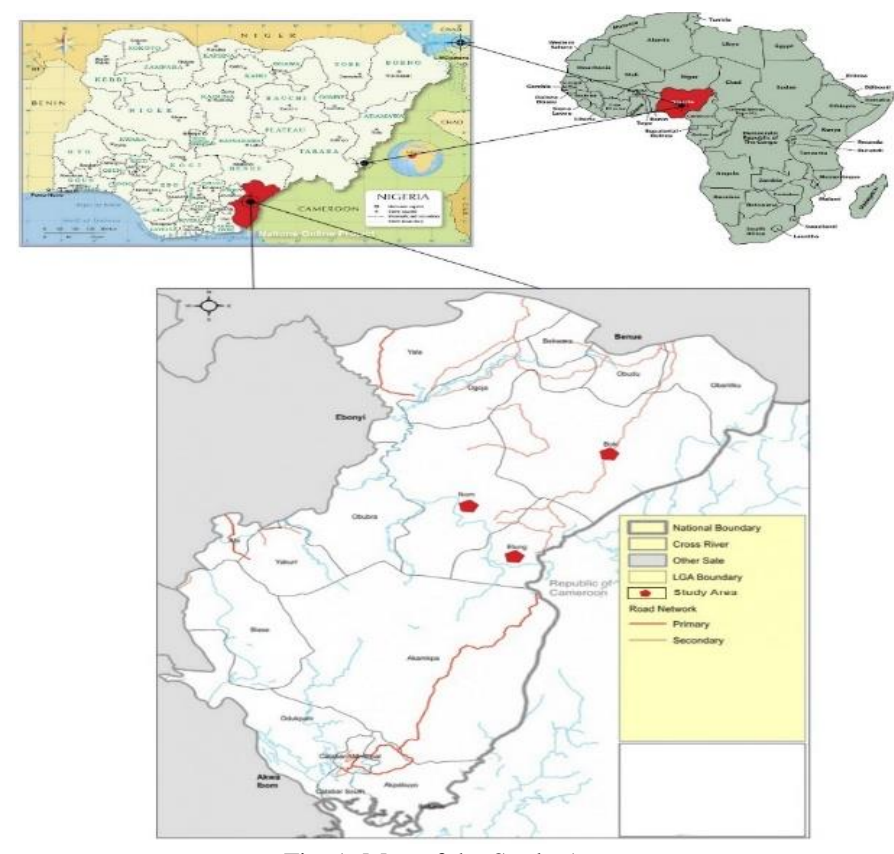

Fig. 1. Map of the Study Area.

Dr. Utietiang L. Undie, Cross River University of Technology, Nigeria. (e-mail: utietiangundie ${ }^{\circledR}$ gmail.com) 


\section{Soil Sampling}

In each selected cocoa farm, two Quadrats of $50 \times 50 \mathrm{~m}$ were marked. In each Quadrat, three representative core samples were collected randomly at depths of $0-25 \mathrm{~cm}$ and $25-50 \mathrm{~cm}$ using soil auger and bulked together for each depth to form a composite sample. A total of 36 representative soil samples were collected, bagged, and labeled in sampling bags. These were transported to Federal University of Agriculture, Makurdi, Nigeria for standard laboratory analysis.

\section{Soil Analysis}

Prior to physicochemical analysis, the soils were air dried under room temperature, sieved through a $2 \mathrm{~mm}$ mesh.

Particle size distribution (PSD): was determined by the Bouyoucos (Hydrometer) method procedure by [8]. This involves the suspension of soil samples with sodium hexametaphophate (calgon). The reading on the hydrometer was taken at 40 seconds. Second reading was taken three hours later. The particle size was then calculated using the following formula:

$$
\begin{gathered}
\text { Sand }=100-\left(\mathrm{H}_{1}+0.2\left(\mathrm{~T}_{1}-68\right)-2.0\right) 2 \\
\text { Clay }=\left(\mathrm{H}_{2}+0.2\left(\mathrm{~T}_{2}\left(\mathrm{~T}_{2}-68\right)-2.0\right) 2\right. \\
\text { Silt }=100-(\% \text { sand }+\% \text { clay })
\end{gathered}
$$

where:

$\mathrm{H}_{1}=$ Hydrometer first reading at 40 seconds.

$\mathrm{T}_{1}=$ temperature first reading at 40 seconds.

$\mathrm{H}_{2}=$ Hydrometer second reading after 3 hours.

$\mathrm{T}_{2}=$ Temperature second reading after 3 hours.

\section{Soil $p H$}

This was determined in both water and $0.1 \mathrm{~N} \mathrm{KCL}$ in a ratio of 1:1 soil: water and 1:2.5 soil: $\mathrm{KCl}$ respectively. After stirring the soil suspension for 30 minutes, the $\mathrm{pH}$ value was read using the glass electrode $\mathrm{pH}$ meter [9].

\section{Organic Matter}

This was determined by the walkley-Black method as outlined by [10] which involves the oxidation with dichromate and tetraoxosulphate vi acid $\left(\mathrm{H}_{2} \mathrm{SO}_{4}\right)$. The excess was titrated against Ferrous Sulphate. The organic carbon was then calculated using the relationship:

$$
\% \operatorname{org} . C=\frac{N\left(V_{1}-V_{2}\right)}{W} \times 0.3 f
$$

where:

$\mathrm{N}=$ Normality of Ferous Sulphate solution.

$\mathrm{V}_{1}=\mathrm{Ml}$ Ferrous Ammonium Sulphate for the black.

$\mathrm{V}_{2}=\mathrm{ml}$ Ferrous Ammonium Sulphate for the sample.

$\mathrm{W}=$ mass of sample $=$ farm.

$\mathrm{f}=$ correction factor $=1.33$.

$\%$ organic matter in soil $=\%$ org. $\mathrm{C} \times 1.729$.

\section{Nitrogen in soil}

Total nitrogen in soil was determined by the macro Kjeldahl method as described by [8]. The soil samples were digested with Tetraoxosulphate (VI) acid $\left(\mathrm{H}_{2} \mathrm{SO}_{4}\right)$ after addition of excess caustic soda. This was distilled into a $2 \%$
Boric acid $\left(\mathrm{H}_{3} \mathrm{BO}_{4}\right)$ and then titrated with $0.01 \mathrm{HCl}$. And the nitrogen was obtained from the relationship.

$$
\% N=\frac{T \times M \times 14}{N} \times 100
$$

where:

$\mathrm{T}=$ Titre value.

$\mathrm{M}=$ Molarity of $\mathrm{HCl}$.

$\mathrm{W}=$ Weight of soil used.

$\mathrm{N}=$ Normality of $\mathrm{H}_{2} \mathrm{SO}_{4}$.

\section{Available phosphorus}

Available $\mathrm{P}$ was determined by Bray 1 method as outlined by [10]. This involved mechanical shaking of the sample in an extracting solution then centrifuging the suspension at 2000 rotations per minutes for 10 minutes. Using ascorbic acid method, the percentage transmittance on the spectrophotometer at $660 \mathrm{~nm}$ wavelength was measured. The optical density (OD) of the standard solution was then plotted against the phosphorus ppm and the extractable $\mathrm{P}$ of the soil was then calculated.

5. Cation Exchange capacity (CEC) and Exchangeable acidity (EA)

These were determined by the Kjeldahl distillation and titration method as outlined by [11]. Using ammonium acetate solution, the soil samples were leached then the soil washed with methyl alcohol and allowed to dry. The soil was then distilled in Kjeldahl operation in to a $4 \%$ Boric acid solution. The distillate was then titrated with standard solution of $0.1 \mathrm{~N} \mathrm{HCl}$.

\section{Exchangeable cations}

This was determined by ammonium acetate extraction method as described by [11]. The soil samples were shaken for 2 hours then centrifuged at $2000 \mathrm{rpm}$ for 5-10 minutes after decanting into a volumetric flask, ammonium acetate $(30 \mathrm{ml})$ was added again and shaken for 30 minutes, centrifuged and the supernatant transferred into same volumetric flask. Atomic Absorption spectrophotometer (AAS) was used to read the cations.

\section{RESUlts AND DisCUSSION \\ A. Physical Properties of the Soils}

Results of particle size distribution and textural classification of soils in Boki, Ikom, and Etung are presented in Table 1.

The percentage sand composition of Boki soils ranged from $40.20-80.00$ with a mean value of $60.52 \%$ at the 0 $25 \mathrm{~cm}-50 \mathrm{~cm}$, The silt content of the soils range from $10.00 \%-$ $23.00 \%$ with a mean value of $13.20 \%$ in soil depth of $0-$ $50 \mathrm{~cm}$. The clay content ranged from $10.00 \%-36.00 \%$ with a mean value for the $26.28 \%$. The value for the $0-25 \mathrm{~cm}$ of the soil separates were higher than the $25 \mathrm{~cm}-50 \mathrm{~cm}$. The textural classes for the Boki cocoa soils were loamy sand and sandy loam for the $0-25 \mathrm{~cm}$ depth of Bunyia soils and sandy loan and sandy clay loan for the 25-50 depth soils of farms:Bunyia. The textural classes of Bashua indicated the soils as sandy loan and loaning sand for the $0-25 \mathrm{~cm}$ depth and sandy clay loan for the $25-50 \mathrm{~cm}$ depth. The Olum soils textural classes were sandy clay and clay loan. 
Ikom soils particle size distribution showed sand ranges from $42.00 \%-72.20 \%$ at the $0-50 \mathrm{~cm}$ depth with a mean of $56.01 \%$ The percentage silt content of the soils ranged from $7.80-16.00 \%$ with a mean value of $13.26 \%$. The clay content of Ikom soils range from $18.00 \%-44.00 \%$ with a mean of $30.65 \%$ the texture classes of Ikom cocoa producing soil of Okuni were predominantly sandy loan. The last Motor soil showed the soil to be clay loam with same trend in Akparabog soils that showed clay loam of depths of 25$50 \mathrm{~cm}$.

The soils of Etung cocoa farms of Agbokim, Bendegle and Ajassor have particle size distribution range of $39.40 \%-70 \%$ with a mean of $52.77 \%$. The silt content ranged from $7.80 \%$ - 1980 for the $0-50 \mathrm{~cm}$ soil depth with a mean of $14.02 \%$ while the clay content ranged from $22.20 \%-42.40 \%$ for the soil depth of $0-50 \mathrm{~cm}$ with a mean value of $33.13 \%$. Textural classes of Bendeghe was sandy loam at all the $0-50 \mathrm{~cm}$ depth except for one farm whose soil was sandy loam at the 0$25 \mathrm{~cm}$. The texture for all the farms for Agbokim at all depth was clay loam. Ajassor I cocoa farms had a texture of sandy clay while farms at Ajassor II were clay loam at the $0-25 \mathrm{~cm}$ and sandy-clay loam at the $25-50 \mathrm{~cm}$ depth.

The location of textural soil classes which indicated five for Boki (Loamy sand, sandy loam, sandy clay loam, sandy clay and clay loam); Ikom (four) sandy loam, sandy clay loam, sandy clay and clay loam and three textural classes for Etung (sandy loam, sandy clay loam and clay loam) is an indication of spatial heterogeneity in soil parent materials. This variability of textures in these major cocoa producing areas is in line with the studies of [12] whose findings indicated that geology of central Cross River State which include in addition other Local Government Areas, Boki, Ikom and Ekung, comprise majorly of sand stones, silt stone, shale-Basalt and basement complex. The clay content of the soils has earlier been observed by [13] who reported that red clay is found within Ikom, Etung, some parts of Boki and Obubra described as ferruginous tropical soils. Soil texture is a very important property of soils as it regulates moisture, nutrients, and pollutant movement in the rhizosphere. The textural classes of these soils fall within the range recommended by [14] who stated that a model profile of cocoa growing soil should be deep well drained soil over sandy clay layer. This soil textural range also were recommended by [15] to the deep soils characterized by sandy clay, clay, and silt clay textures. The clay sand ratio in all these textural classes is indicative of the good drainage status which prevents excess soil moisture and consequent shortages of oxygen for good root development of cocoa as observed by [16], [17].

\section{B. Soil pH, Electrical Conductivity (EC), Total N, Av. P, OM (Table 2)}

$\mathrm{pH}$ of Boki soils ranged from 5.2-6.10 for the $0-50 \mathrm{~cm}$ depth for the farms in Bunyia, Bashua and Olum with a mean of 5.64. Ikom soils of Akparabong last motor as Okuni pH raped from 5.00-5.6with a mean of 5.31 while soil $\mathrm{pH}$ of Etung cocoa farms in Bendeghe Agbokinm Ajasor range from 4.80-70.10 with a mean of 5.39.

The electrical conductivity (EC) of Boki soils ranged from $0.011 \mathrm{ds} l m-0.031 \mathrm{dslm}$ with a mean $0.022 \mathrm{ds} / \mathrm{m}$. the EC of Etung cocoa farm soils ranged from $2.55-557$ with a mean of 3.36\% Ikom 2.04-3.81 with a mean of $2.96 \%$ and Etung $1.87-4.59$ with a mean of $2.96 \%$. Total $\mathrm{N}$ ranged from $0.06-$ 0.12 with a mean of $0.9 \%$ in Boki cocoa farm soils, Ikom $0.05-0.10$ with a mean of $0.07 \%$ while total $\mathrm{N}$ for Etung soils range from $0.06-0.12$ with a mean of $0.08 \%$. Available $\mathrm{P}$ range from $3.40-9.17 \mathrm{cmol} / \mathrm{kg}$ with a mean of $5.08 \mathrm{cmol} / \mathrm{kg}$ - Boki; $3.00-11.51 \mathrm{cmol} / \mathrm{kg}$ with a mean of $5.90 \mathrm{cmol} / \mathrm{kg}$ in Ikom and $1.00-5.36 \mathrm{cmol} / \mathrm{kg}$ with mean of $2.82 \mathrm{cmol} / \mathrm{kg}$ with of $2.82 \mathrm{cmol} / \mathrm{kg}$ in Etung.

\section{Exchangeable Bases and Acidity (EA) ECEC and Base Saturation (BS) (Table 3)}

The concentration of $\mathrm{K}$-bola cocoa from soils range from $0.09-0.17$ with a mean of $0.12 \mathrm{cmol} / \mathrm{kg}$. in Ikom the range was $0.01-0.14 \mathrm{cmol} / \mathrm{kg}$ with a mean value of $10 \mathrm{cmol} / \mathrm{kg}$ and in Etung the $\mathrm{k}$ range from 0.09-0.14 with a mean of $0.11 \mathrm{cmol} / \mathrm{kg} \mathrm{Ca}$ in Boki range from 4.00-6.00 cmol/ $\mathrm{kg}$ with a mean of $5.18 \mathrm{cmol} / \mathrm{kg}$. Ikom was $3.02-8.00 \mathrm{cmol} / \mathrm{kg}$ with a mean of $5.26 \mathrm{cmol} / \mathrm{kg}$ while $\mathrm{Ca}$ in Etung range from 2.40$8.90 \mathrm{cmol} / \mathrm{kg}$ with a mean of $3.80 \mathrm{cmol} / \mathrm{kg}$. $\mathrm{Mg}$ range from $1.40-2.7 \mathrm{cmol} / \mathrm{kg}$ with a mean of $2.00 \mathrm{cmol} / \mathrm{kg}$ for Boki soil; $1.40-3.00 \mathrm{cmol} / \mathrm{kg}$ with a mean of $1.98 \mathrm{in}$ Ikom and $1.20-2.80$ $\mathrm{cmol} / \mathrm{kg}$ - with a mean of $1.47 \mathrm{cmol} / \mathrm{kg}$ Etung soils. Exch. $\mathrm{Na}$ was $0.03-0.07 \mathrm{cmol} / \mathrm{kg}$ with a mean of $0.5 \mathrm{cmol} / \mathrm{kg}$ in Boki, $0.05-0.08 \mathrm{cmol} / \mathrm{kg}$ - Ikom with a mean of $0.06 \mathrm{cmol} / \mathrm{kg}$ while in Etung it was $0.04-0.07 \mathrm{cmol} / \mathrm{kg}$ with a mean of 0.06 $\mathrm{cmol} / \mathrm{kg}$. ECEC ranged from $7.78-10.62 \mathrm{cmol} / \mathrm{kg}$ with a mean of $8.97 \mathrm{cmol} / \mathrm{kg}$ in Boki, $5.96-12.65 \mathrm{cmol} / \mathrm{kg}$ with mean of $8.94 \mathrm{cmol} / \mathrm{kg}$ - Ikom and 5.09-13.05 with mean of $6.73 \mathrm{cmol} / \mathrm{kg}$ in Etung soils. The base saturation of $78.02-$ $83.71 \%$ with mean of $81.38 \%$ for Boki, $78.80-88.14$ with mean of $82.70 \%$ - Ikom and for Etung it was 70.40-90.80 with mean of $77.25 \%$.

The $\mathrm{pH}$ range of the soils in the three main cocoa producing areas indicated that the soils were moderately to slightly acidic. The mean $\mathrm{pH}$ value of the soils is suitable for cocoa growing ads was within recommended $\mathrm{pH}$ of 5-8 by [18]. This is also in line with the assertions of [19], [20] that Cocoa in West Africa and Brazil is widely grown on soils with either neutral or slightly acidic infertile soils.

With exception of Total $\mathrm{N}$ (in Boki) $\mathrm{Ca}, \mathrm{Mg}$ and Base Saturation, all other nutrients were below critical limits for cocoa productions.

Nitrogen content in Boki soils was adequate for cocoa cultivation as the value was $0.09 \%$ of $\mathrm{N}$ for cocoa [21], [19]. The higher $\mathrm{N}$ content of Boki cocoa soils could be attributed to the higher OM content of the farms over that of Ikom and Ekung (Table 2). The report of [22] had earlier stated that $\mathrm{N}$ in litter (Organic matter) in cocoa farms is higher than the $\mathrm{N}$ exported from cocoa beans harvest. 
TABLE 1: SOIL PHYSICAL PROPERTIES OF THE STUDY AREA

Ikom

Etung

Boki

\begin{tabular}{|c|c|c|c|c|c|c|c|c|c|c|c|c|c|c|c|c|c|c|}
\hline $\mathrm{S} / \mathrm{N}$ & Location & Depth $\mathrm{cm}$ & Sand $\%$ & Silt $\%$ & Clay $\%$ & $\begin{array}{c}\text { Textural } \\
\text { Class }\end{array}$ & Location & Depth $\mathrm{cm}$ & Sand & Silt & Clay & $\begin{array}{c}\text { Textural } \\
\text { Class }\end{array}$ & Location & Depth $\mathrm{cm}$ & Sand $\%$ & Silt $\%$ & Clay $\%$ & $\begin{array}{c}\text { Textural } \\
\text { Class }\end{array}$ \\
\hline 1 & & $0-25 \mathrm{~cm}$ & 54.00 & 9.60 & 36.40 & $\mathrm{SC}$ & & $0-25 \mathrm{~cm}$ & 54.00 & 17.80 & 28.20 & SCL & & $0-25 \mathrm{~cm}$ & 74.20 & 12.80 & 13.00 & SL \\
\hline 2 & Aparabong 1 & $25-50 \mathrm{~cm}$ & 42.00 & 13.60 & 44.40 & $\mathrm{CL}$ & Bendeghe I & $25-50 \mathrm{~cm}$ & 50.00 & 19.80 & 30.20 & SCL & Bunyia I & $25-50 \mathrm{~cm}$ & 72.00 & 12.00 & 16.00 & SL \\
\hline 3 & & $0-25 \mathrm{~cm}$ & 44.00 & 15.60 & 40.40 & $\mathrm{CL}$ & & $0-25 \mathrm{~cm}$ & 70.00 & 7.80 & 22.20 & SL & & $0-25 \mathrm{~cm}$ & 62.20 & 13.80 & 24.00 & SL \\
\hline 4 & Aparabong II & $25-50 \mathrm{~cm}$ & 46.00 & 15.60 & 38.40 & $\mathrm{CL}$ & Bendeghe II & $25-50 \mathrm{~cm}$ & 64.00 & 7.80 & 28.20 & SCL & Bunyıa II & $25-50 \mathrm{~cm}$ & 48.20 & 15.80 & 36.00 & SCL \\
\hline 5 & & $0-25 \mathrm{~cm}$ & 58.00 & 16.00 & 26.00 & SCL & & $0-25 \mathrm{~cm}$ & 54.00 & 13.80 & 32.20 & $\mathrm{CL}$ & & $0-25 \mathrm{~cm}$ & 68.00 & 12.00 & 20.00 & SL \\
\hline 6 & Last Motor I & $25-50 \mathrm{~cm}$ & 54.15 & 14.24 & 31.61 & $\mathrm{CL}$ & Agbokim I & $25-50 \mathrm{~cm}$ & 50.0 & 13.60 & 36.40 & $\mathrm{CL}$ & Bashua I & $25-50 \mathrm{~cm}$ & 59.20 & 13.20 & 27.60 & SCL \\
\hline 7 & & $0-25 \mathrm{~cm}$ & 58.20 & 5.80 & 36.00 & CL & & $0-25 \mathrm{~cm}$ & 46.00 & 13.60 & 40.40 & $\mathrm{CL}$ & & $0-25 \mathrm{~cm}$ & 80.00 & 10.00 & 10.00 & LS \\
\hline 8 & Last Motor II & $25-50 \mathrm{~cm}$ & 48.00 & 15.80 & 36.00 & $\mathrm{CL}$ & Agbokim II & $25-50 \mathrm{~cm}$ & 46.00 & 13.00 & 40.40 & $\mathrm{CL}$ & Bashua II & $25-50 \mathrm{~cm}$ & 64.00 & 10.00 & 26.00 & SCL \\
\hline 9 & Okuni I & $0-25 \mathrm{~cm}$ & 57.00 & 16.00 & 27.00 & $\mathrm{CL}$ & & $0-25 \mathrm{~cm}$ & 45.40 & 14.20 & 40.40 & $\mathrm{SC}$ & & $0-25 \mathrm{~cm}$ & 58.20 & 5.80 & 36.00 & $\mathrm{SC}$ \\
\hline 10 & Okuni I & $25-50 \mathrm{~cm}$ & 52.15 & 15.24 & 32.61 & $\mathrm{CL}$ & Ajassor I & $25-50 \mathrm{~cm}$ & 39.40 & 18.20 & 42.40 & $\mathrm{SC}$ & Olum I & $25-50 \mathrm{~cm}$ & 48.20 & 15.80 & 36.00 & $\mathrm{CL}$ \\
\hline 11 & & $0-25 \mathrm{~cm}$ & 64.00 & 10.00 & 26.00 & $\mathrm{CL}$ & & $0-25 \mathrm{~cm}$ & 50.20 & 17.80 & 32.00 & & & $0-25 \mathrm{~cm}$ & 51.80 & 13.40 & 34.80 & $\mathrm{CL}$ \\
\hline 12 & Okuni II & $25-50 \mathrm{~cm}$ & 57.20 & 16.80 & 36.00 & $\mathrm{CL}$ & Ajassor II & $25-50 \mathrm{~cm}$ & 52.77 & 14.02 & 33.13 & LSC & Olum II & $25-50 \mathrm{~cm}$ & 40.20 & 23.80 & 36.00 & CL \\
\hline
\end{tabular}

LS= Loamy Sand, SL=Sandy loam, SCL=Sandy Clay Loam, SC=Sandy Clay, CL=Clay Loam.

TABLE 2: FeRTILITY PROPERTIES OF THE COCOA SOILS

\begin{tabular}{|c|c|c|c|c|c|c|c|c|c|c|c|c|c|c|c|c|c|c|c|}
\hline \multirow[b]{2}{*}{$\mathrm{S} / \mathrm{N}$} & \multirow[b]{2}{*}{ Location } & \multicolumn{6}{|c|}{ Ikom } & \multicolumn{6}{|c|}{ Etung } & \multicolumn{6}{|c|}{ Boki } \\
\hline & & $\begin{array}{l}\text { Depth } \\
\text { cm }\end{array}$ & $\mathrm{Ph}$ & $\begin{array}{c}\text { Ec } \\
\text { Ds/M }\end{array}$ & $\begin{array}{c}\mathrm{Om} \\
\%\end{array}$ & $\begin{array}{l}\text { Total } \\
\mathrm{N} \%\end{array}$ & $\begin{array}{c}\text { Av. P } \\
\mathrm{Mg} / \mathrm{Kg}\end{array}$ & Location & $\mathrm{Ph}$ & $\begin{array}{c}\text { Ec } \\
\text { Ds/M }\end{array}$ & $\begin{array}{c}\mathrm{Om} \\
\%\end{array}$ & $\begin{array}{l}\text { Total } \\
\mathrm{N} \%\end{array}$ & $\begin{array}{c}\text { Av. P } \\
\mathrm{Mg} / \mathrm{Kg}\end{array}$ & Location & $\mathrm{Ph}$ & $\begin{array}{c}\text { Ec } \\
\text { Ds/M }\end{array}$ & $\begin{array}{c}\mathrm{Om} \\
\%\end{array}$ & $\begin{array}{l}\text { Total } \\
\mathrm{N} \%\end{array}$ & $\begin{array}{r}\text { Av. P } \\
\mathrm{Mg} / \mathrm{Kg}\end{array}$ \\
\hline 1 & \multirow{2}{*}{ Aparabong I } & $0-25 \mathrm{~cm}$ & 5.10 & 0.022 & 3.37 & 0.08 & 7.01 & \multirow{2}{*}{ Bendeghe I } & 7.10 & 0.021 & 2.89 & 0.07 & 1.67 & \multirow{2}{*}{ Bunyia I } & 6.00 & 0.023 & 5.57 & 0.11 & 3.80 \\
\hline 2 & & $25-50 \mathrm{~cm}$ & 5.30 & 0.040 & 3.81 & 0.10 & 11.51 & & 5.90 & 0.018 & 2.90 & 0.08 & 1.60 & & 5.80 & 0.021 & 2.55 & 0.08 & 4.60 \\
\hline 3 & \multirow{2}{*}{ Aparabong II } & $0-25 \mathrm{~cm}$ & 5.10 & 0.041 & 2.72 & 0.06 & 3.50 & \multirow{2}{*}{ Bendeghe II } & 5.80 & 0.013 & 4.59 & 0.12 & 4.50 & \multirow{2}{*}{ Bunyia II } & 6.10 & 0.031 & 4.25 & 0.12 & 5.80 \\
\hline 4 & & $25-50 \mathrm{~cm}$ & 5.20 & 0.031 & 2.21 & 0.08 & 5.00 & & 6.40 & 0.014 & 4.30 & 0.11 & 5.36 & & 5.9 & 0.024 & 3.84 & 0.07 & 4.40 \\
\hline 5 & \multirow[b]{2}{*}{ Last Motor I } & $0-25 \mathrm{~cm}$ & 5.40 & 0.026 & 3.13 & 0.08 & 3.40 & \multirow{2}{*}{ Agbokim I } & 5.00 & 0.020 & 3.64 & 0.10 & 5.50 & \multirow[b]{2}{*}{ Bashua I } & 5.30 & 0.011 & 3.33 & 0.10 & 5.00 \\
\hline 6 & & $25-50 \mathrm{~cm}$ & 5.20 & 0.026 & 2.79 & 0.07 & 3.40 & & 4.80 & 0.023 & 2.38 & 0.06 & 2.34 & & 5.20 & 0.022 & 2.21 & 0.08 & 3.40 \\
\hline 7 & \multirow{2}{*}{ Last Motor II } & $0-25 \mathrm{~cm}$ & 5.70 & 0.016 & 3.23 & 0.08 & 4.84 & \multirow{2}{*}{ Agbokim II } & 5.20 & 0.040 & 2.89 & 0.07 & 2.01 & \multirow{2}{*}{ Bashua II } & 5.30 & 0.020 & 3.23 & 0.09 & 5.10 \\
\hline 8 & & $25-50 \mathrm{~cm}$ & 5.60 & 0.020 & 3.24 & 0.07 & 2.20 & & 4.90 & 0.042 & 1.87 & 0.05 & 1.17 & & 5.20 & 0.021 & 2.55 & 0.06 & 3.62 \\
\hline 9 & \multirow{2}{*}{ Okuni I } & $0-25 \mathrm{~cm}$ & 5.55 & 0.017 & 2.98 & 0.09 & 6.40 & \multirow{2}{*}{ Ajassor I } & 4.90 & 0.030 & 2.89 & 0.07 & 1.50 & \multirow{2}{*}{ Olum I } & 5.70 & 0.016 & 3.23 & 0.08 & 4.84 \\
\hline 10 & & $25-50 \mathrm{~cm}$ & 5.20 & 0.019 & 2.84 & 0.07 & 5.80 & & 4.80 & 0.031 & 2.58 & 0.06 & 1.00 & & 5.60 & 0.020 & 3.24 & 0.07 & 5.84 \\
\hline 11 & \multirow{2}{*}{ Okuni II } & $0-25 \mathrm{~cm}$ & 5.40 & 0.021 & 3.05 & 0.10 & 7.10 & \multirow{3}{*}{ Ajassor II } & 4.90 & 0.032 & 2.61 & 0.07 & 5.00 & \multirow{3}{*}{ Olum II } & 6.00 & 0.021 & 2.72 & 0.06 & 9.17 \\
\hline 12 & & $25-50 \mathrm{~cm}$ & 5.12 & 0.019 & 2.91 & 0.08 & 5.40 & & 5.00 & 0.030 & 2.00 & 0.06 & 2.17 & & 5.60 & 0.024 & 3.58 & 0.10 & 5.42 \\
\hline & Mean & & 5.31 & 0.022 & 2.81 & 0.07 & 5.90 & & 5.39 & 0.026 & 2.96 & 0.08 & 2.82 & & 5.64 & 0.021 & 3.36 & 0.08 & 5.08 \\
\hline
\end{tabular}

$\mathrm{EC}=$ Electrical Conductivity, $\mathrm{OM}=$ Organic matter, $\mathrm{T} . \mathrm{N}=$ Total Nitrogen, Av. $\mathrm{P}=$ available Phosphorus.

TABLE 3: EXChANGEABLE CATIONS OF THE COCOA SOILS

\begin{tabular}{|c|c|c|c|c|c|c|c|c|c|c|c|c|c|c|c|c|c|c|c|c|c|c|c|c|}
\hline \multirow[b]{3}{*}{$\begin{array}{l}\mathrm{S} / \\
\mathrm{N}\end{array}$} & \multicolumn{8}{|c|}{ Ikom } & \multicolumn{8}{|c|}{ Etung } & \multicolumn{8}{|c|}{ Boki } \\
\hline & \multicolumn{8}{|c|}{ Exhangeable Bases cmol/kg } & \multicolumn{8}{|c|}{ Exhangeable Bases cmol $/ \mathrm{kg}$} & \multicolumn{8}{|c|}{ Exhangeable Bases cmol/kg } \\
\hline & Location & $\begin{array}{c}\text { Depth } \\
\mathrm{cm}\end{array}$ & $\mathrm{Ca}$ & $\mathrm{Mg}$ & $\mathrm{K}$ & $\begin{array}{c}\mathrm{EA} \\
\mathrm{cmol} / \\
\mathrm{kg}\end{array}$ & $\begin{array}{c}\text { ECEC } \\
\mathrm{cmol} / \\
\mathrm{kg}\end{array}$ & $\begin{array}{c}\text { BASL } \\
\text { SAT. } \\
\% \\
\end{array}$ & Location & $\mathrm{Ca}$ & $\mathrm{Mg}$ & $\mathrm{Na}$ & $\mathrm{K}$ & $\begin{array}{c}\mathrm{EA} \\
\mathrm{cmol} / \\
\mathrm{kg}\end{array}$ & $\begin{array}{c}\text { ECEC } \\
\mathrm{cmol} / \\
\mathrm{kg}\end{array}$ & $\begin{array}{c}\text { BASL } \\
\text { SAT. } \\
\%\end{array}$ & Location & $\mathrm{Ca}$ & $\mathrm{Mg}$ & $\mathrm{Na}$ & $\mathrm{K}$ & $\begin{array}{c}\mathrm{EA} \\
\mathrm{cmol} / \\
\mathrm{kg} \\
\end{array}$ & $\begin{array}{c}\text { ECEC } \\
\mathrm{cmol} / \\
\mathrm{kg}\end{array}$ & $\begin{array}{c}\text { BASL } \\
\text { SAT. } \\
\%\end{array}$ \\
\hline 1 & \multirow{2}{*}{ Aparabong I } & $0-25 \mathrm{~cm}$ & 3.02 & 1.40 & 0.01 & 1.30 & 5.96 & 78.19 & \multirow{2}{*}{ Bendeghe I } & 3.20 & 1.40 & 0.05 & 0.12 & 1.03 & 5.80 & 82.24 & \multirow{2}{*}{ Bunyia I } & 0.12 & 5.40 & 1.4 & 0.05 & 1.40 & 8.37 & 82.27 \\
\hline 2 & & $25-50 \mathrm{~cm}$ & 6.00 & 2.00 & 0.11 & 1.20 & 9.36 & 87.18 & & 4.00 & 1.30 & 0.07 & 0.09 & 1.20 & 5.66 & 78.8 & & 0.13 & 5.10 & 2.0 & 0.04 & 1.50 & 8.77 & 82.90 \\
\hline 3 & \multirow[b]{2}{*}{ Aparabong II } & $0-25 \mathrm{~cm}$ & 4.00 & 1.40 & 0.13 & 1.60 & 7.30 & 78.08 & \multirow[b]{2}{*}{ Bendeghe II } & 4.40 & 1.40 & 0.06 & 0.10 & 1.30 & 7.26 & 82.09 & \multirow[b]{2}{*}{ Bunyia II } & 0.11 & 5.30 & 2.4 & 0.06 & 1.60 & 9.47 & 83.10 \\
\hline 4 & & $25-50 \mathrm{~cm}$ & 4.40 & 1.50 & 0.14 & 1.30 & 7.42 & 82.48 & & 8.90 & 2.80 & 0.05 & 0.10 & 1.20 & 13.05 & 90.80 & & 0.13 & 4.80 & 2.2 & 0.05 & 1.40 & 8.58 & 83.68 \\
\hline 5 & \multirow[b]{2}{*}{ Last Motor } & $0-25 \mathrm{~cm}$ & 5.20 & 1.80 & 0.10 & 1.54 & 8.70 & 82.30 & \multirow[b]{2}{*}{ Agbokim I } & 2.40 & 1.20 & 0.06 & 0.13 & 1.40 & 5.09 & 72.50 & \multirow[b]{2}{*}{ Bashua I } & 0.16 & 5.20 & 1.90 & 0.07 & 1.50 & 8.83 & 83.11 \\
\hline 6 & & $25-50 \mathrm{~cm}$ & $\begin{array}{l}5.21 \\
4.67\end{array}$ & $\begin{array}{l}1.60 \\
1.67\end{array}$ & $\begin{array}{l}0.12 \\
0.12\end{array}$ & $\begin{array}{l}1.50 \\
1.41\end{array}$ & $\begin{array}{l}8.49 \\
7.89\end{array}$ & $\begin{array}{l}82.33 \\
81.76\end{array}$ & & 2.80 & 1.30 & 0.06 & 0.09 & 1.50 & 5.74 & 73.87 & & 0.17 & 5.60 & 2.00 & 0.06 & 1.54 & 9.37 & 83.56 \\
\hline 7 & \multirow[b]{2}{*}{ Last Motor II } & $0-25 \mathrm{~cm}$ & 6.00 & 2.70 & 0.12 & 1.73 & 10.62 & 83.71 & \multirow[b]{2}{*}{ Agbokim II } & 2.80 & 1.20 & 0.06 & 0.09 & 1.50 & 5.65 & 73.45 & \multirow[b]{2}{*}{ Bashua II } & 0.13 & 5.40 & 2.10 & 0.05 & 1.52 & 9.20 & 83.48 \\
\hline 8 & & $25-50 \mathrm{~cm}$ & 4.00 & 1.60 & 0.09 & 1.62 & 7.73 & 78.66 & & 4.00 & 1.30 & 0.07 & 0.11 & 1.60 & 7.07 & 77.37 & & 0.12 & 5.40 & 2.00 & 0.05 & 1.55 & 9.12 & 83.00 \\
\hline 9 & \multirow[b]{2}{*}{ Okuni I } & $0-25 \mathrm{~cm}$ & 7.01 & 2.50 & 0.11 & 1.64 & 11.01 & 87.73 & \multirow[b]{2}{*}{ Ajassor I } & 3.20 & 1.50 & 0.04 & 0.16 & 1.82 & 6.72 & 72.92 & \multirow[b]{2}{*}{ Olum I } & 0.12 & 6.00 & 2.70 & 0.07 & 1.73 & 10.62 & 83.70 \\
\hline 10 & & $25-50 \mathrm{~cm}$ & 5.50 & 1.53 & 0.09 & 1.66 & 9.10 & 78.90 & & 2.70 & 1.40 & 0.06 & 0.10 & 1.79 & 6.05 & 70.41 & & 0.09 & 4.00 & 1.60 & 0.06 & 1.62 & 7.37 & 78.02 \\
\hline 11 & \multirow{2}{*}{ Okuni II } & $0-25 \mathrm{~cm}$ & 6.40 & 2.80 & 0.12 & 1.71 & 12.01 & 78.10 & \multirow{2}{*}{ Ajassor II } & 3.20 & 1.40 & 0.06 & 0.13 & 1.60 & 6.38 & 75.08 & \multirow{2}{*}{ Olum II } & 0.11 & 5.60 & 2.20 & 0.06 & 1.60 & 9.58 & 83.30 \\
\hline 12 & & $25-50 \mathrm{~cm}$ & 6.10 & 1.92 & 0.08 & 1.61 & 9.91 & 82.24 & & 4.00 & 1.50 & 0.05 & 0.14 & 1.66 & 7.35 & 77.41 & & 0.09 & 4.40 & 1.60 & 0.03 & 1.66 & 7.78 & 78.66 \\
\hline & Mean & & 5.26 & 1.98 & 0.10 & 1.50 & 8.94 & 82.70 & Mean & 3.80 & 1.17 & 0.06 & 0.11 & 1.47 & 6.73 & 77.25 & Mean & 5.18 & 2.00 & 0.05 & 0.12 & 1.55 & 8.79 & 81.38 \\
\hline
\end{tabular}

EA= Exchangeable acidity, BS= Base Saturation, ECEC= Effective Cation Exchange Capacity. 
Apart from some farms in Etung, the values obtained for exchangeable $\mathrm{Ca}$ from the farms in Boki and Ikom were adequate for cocoa production as these were above $5.0 \mathrm{cmol} / \mathrm{kg}$ as recommended by [17] and [18]. The deficiency of ca in Nigerian cocoa soils in rare as Concentration of ca in these study area agree with the studies of [23].The $\mathrm{Mg}$ content of all the cocoa farms investigated were higher than the critical level of $0.9 \mathrm{cmol} / \mathrm{kg}$ as stated by [23]. The concentration of exchangeable $\mathrm{Mg}$ in cocoa farms soils of Boki, Ikom and above critical level differs from earlier studies by [24] and [23]. The moderate content of the $\mathrm{p} \%$ sand in relation to clay could have reduced leaching of Exch. Mg. The base saturation of all the investigated soil s was higher than the critical level of 60\% [18] for good production of cocoa. Aluminum toxicity resulting from acidity of soils is a major of soils whose $\mathrm{pH}$ is moderately and slightly acidic the combination of likely toxicities of $\mathrm{Al}, \mathrm{H}$, $\mathrm{Mn}$ and $\mathrm{Fe}$ can induce deficiencies of $\mathrm{N}, \mathrm{P}, \mathrm{Mg} \mathrm{Ca}, \mathrm{K}$ and $\mathrm{Zn}$ [25]. The base saturation of Boki, Ikom and Etung (Table 3) indicate promising suitability of the soils for nutrients availability as aluminium toxicity is not envisaged as [26] stated that a non-acid cation saturation $\geq$ soils will not likely be the problem of $\mathrm{Al}$ toxicity.

Available $\mathrm{p}$ in all the investigated cocoa farms in the three location was low (table 2) below the critical level of $10 \mathrm{mg} / \mathrm{kg}$. The low P in these soils (Southern Nigeria) is similar to the reported low values in cocoa farm soils of South Western Nigeria by [27]. The K concentration in the cocoa soils of the study area is below the critical level of $0.25 \mathrm{cmol} / \mathrm{kg}$ [18]. The low $\mathrm{P}$ and $\mathrm{K}$ of soils in Etung (Ajassor and Agbokim) were similar to the findings of [28]. Although the pathways of $\mathrm{P}$ and $\mathrm{K}$ release and availability are not the same, application of these elements through inorganic fertilizers to the cocoa farms will increase yield of cocoa.

$\mathrm{OM}$ and EC levels of the cocoa soils of Boki, Ikom and Etung were low as below the critical limits, as established and recommended by [18] for cocoa producing soils. The low EC of the soils indicates low concentration of soluble salts [26] which is conducive for cocoa production. The implication of low OM in these soils is low availability of adequate nutrient from native organic sources through mineralization. This calls for external intervention with inorganic fertilizers of $\mathrm{N}$ and $\mathrm{P}$ especially that are organic Based. [22] noted that larger amount of $\mathrm{P}$ is removed by beans, while [27] reported that leaf litter in cocoa plantations was not sufficient to supply $\mathrm{P}$ required by cocoa trees for optical yields.

\section{CONCLUSION}

The soil textural classes of these cocoa producing areas with the adequate base saturation levels with $\mathrm{Ca}$ and especially $\mathrm{Mg}$ is an indicator of quality cocoa beans production. But to match quality with quantity, the low levels of $\mathrm{P}, \mathrm{K}, \mathrm{N}, \mathrm{OM}$, and $\mathrm{EC}$ calls for attention and action towards external supplies with appropriate inorganic fertilizers to meet the high nutrients demand of cocoa trees. Application of appropriate fertilizers in these cocoa growing areas will guarantee sustainable production of cocoa beans both in quantity and quality.

\section{ACKNOWLEDGEMENT}

We like to express our gratitude to Priase Eju, Godwin Itokem, Emmanuel Atsu and Nkanu Ideba, our Undergraduate students who assisted so much in the field during soil sampling, conveyance, and processing for laboratory analysis.

\section{REFERENCES}

[1] Verter, N. and Becyarova, V. (2014) Analysis of Some Drivers of Cocoa Export in Nigeria in the Era of Trade Liberalization. Agris On-line Papers in Economics and Informatics 6(4): 208-218.

[2] Iremiren, G.O, Oduwole O; Obatolu, B.O. Aigbekaen, E., Sanusi, R.A., Shittu T.R., Emeku L. E; Iberemo, O.S; Aikpokpodion, P; Agbeniyi, S.O; Ndubuku, T.C.N; Adeogun, S. and Olaiya, A. (2012) cocoa production survey in Nigeria. Report of cocoa Research Instite of Nigeria (CRIN) ISBN: 9789785065664 84pp.

[3] Tiku, N.E. Galadima, M. and Iyala, D. (2006) Scale efficiency of Cocoa production in Cross River State. Federal University Wukari Trends in Science and Technology Journal Vol. 1 (2)417-422

[4] Ofori-Boateng, K. and Insah, B. (2014) The impact of Climate Change on Cocoa Production in West Africa. International Journal of Climate Change Strategies and Management 6(3) 296.

[5] IITA (2015) International Institute for Tropical Agriculture. Cocoa Development in Nigeria: The Strategic Role of STCP. 34pp.

[6] Fernandez, E.C.M. and P.A. Sanchez (1990). The Role of Organic Input and Soil Organic Matter for Nutrient Cycling in Tropical Soils. In: Pushparajah E. and Lantham M. (eds) Organic Matter Management and Tillage in Humid and Subhumid Africa. No. 10:169-187.

[7] NIMET (2008) Weather Report: Nigeria Meteorological Agency, Ikom, Cross River State.

[8] Udo, E. J., T. O. Ibia, J. O. Ogunwale, A. O. Ano and I. Esu (2009), Manual of Soil, Plant and Water Analysis, 183pp., Sibon Books Ltd. Lagos.

[9] McClean, E. O. (1982), Soil pH and Lime requirement. In: Page D. C. (eds) Methods of Soils Analysis part 2. Chemical and soil microbial properties. Agronomy series No. 9 ASA, SSSA, Madison. Page, A. L., R. H. Miller, and D. R. Keeney (1982). Methods of soil Analysis part 2. Chemical and microbiological properties. American Society of Agronomy, Madison 55 pp.

[10] Page, A. L., R. H. Miller, and D. R. Keeney (1982). Methods of soil Analysis part 2. Chemical and microbiological properties. American Society of Agronomy, Madison $55 \mathrm{pp}$.

[11] IITA (1979) Selected methods for soil and plant analysis. International Institutes for Tropical Agriculture, Ibadan Nigeria. Manual series No. 1.

[12] Amajor, L.C. (1989) thee Eze-Aku sandstone ridge of south Eastern Nigeria. A re-interpretation of their depositional origin. Journal of Mineral Geology 23:17-26.

[13] Floyd, B. (1969). Eastern Nigeria a Geographical Macmillian company limited London pp 67-110.

[14] Anim-Kwapong, G. J. and Frimpong, E. B. (2004)Vulnerability and Adaptation Assessment Under the Netherlands Climate Change Studies Assistance Programme Phase 2 (NCCSAP2): Vulnerability of agriculture to climate change-impact of climate on cocoa production, Cocoa Research Institute of Ghana.

[15] Ritung, S. W; Agus, F. and Hidayat H. (2007) land suitability Evaluation with a case map of Aceh Barat District. Indonesian soil Research Institute and World Agroforestry centre, Boyor Indonesia 42pp.

[16] Hardy F. (1960). Cacao Manual. Inter-American Institute of Agricultural Science, Turrialba, Costa Rica. 134pp.

[17] Smyth, A.J. (1966). The Selection of Soils for Cocoa, Soils Bulletin; No 5, Rome: FAO.

[18] Ibiremo, O.S., Daniel, M.A., Iremiren, G.O. and Fagbola O. (2011) Soil fertility evaluation for Cocoa production in South-eastern Adamawa State, Nigeria. World Journal of Agricultural Science 7(2)218-223.

[19] Aikpokpodion, P.E. (2010) Nutrients dynamics in cocoa soils, leaf and beans in Ondo State, Nigeria. Journal Agricultural Science;1(1):1-9.

[20] Wood, G.A.R. and Lass, R.A. (2001) Cocoa, $4^{\text {th }}$ Edition. Blackwell Science Oxford.

[21] Egbe, N. E., Olatoye, S. and Obatolu C. (1989). Impact of rate and types of fertilizers on productivity and nutrient cycling in tree crop plantation ecosystem. Paper submitted for MAB Workshop, Abuja.

[22] Hartemink, A.E. (2005) Nutrient Stocks, Nutients cycling and soil changes in cocoa ecosystems- a review. Advances in Agronomy 86: 227 - 253. 
[23] Ipinmoroti, R. R., Aikpokpodion, P. E. and Akanbi, O. (2009) Nutritional assessment of Cocoa plots for Soil fertility management on some Cocoa farms in Nigeria. $16^{\text {th }}$ International Cocoa Conference, Indonesia.

[24] Obatolu, C. R. and Chude, V. O. (1987). Soils and Nutritional requirement of cocoa in Nigeria, Review of Soils and Fertilizer Use Research in South Western Nigeria. Lagos: FPDD/FMAWR \&RD.

[25] Baligar, V.C. and Fageria, N.K. (1997) Nutrient use efficiency in acid soils: Nutrient management and plant use efficiency. In Moniz AC, Furlani AMC, Schaffert RE, Fageria NK, Rosolem CA, Cantarella H. (ed.) Plantsoil interactions at low $\mathrm{pH}$. Brazilian Soil Science Society Campinas, Brazil. ;75-95.

[26] Brady, N.C. and Weil, R.R. (2014) Nature and properties of soils (13 ${ }^{\text {th }}$ Edition) Pearson Educational Publishers, New Delhi India.

[27] Ogunlade, M.O. and Aikpokpodion. P.O. (2006) Available phosphorus and some micronutrient contents of cocoa soils in three cocoa growing ecological zones of Nigeria. Proceedings of 15 the International Research Conference, Costa Rica; 2006.

[28] Ajiboye, G, A, Jaiyeoba, J.O, Olaiya A.O and Hammed L.A. (2015) Fertility baseline study of major cocoa Growing Soils of Nigeria and Implication for cocoa production in Nigeria. Nigeria Journey of soil science VOL. 25:45-57.

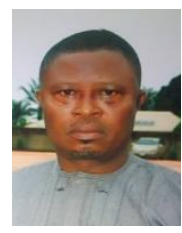

Michael Ati Kekong was born in Bunyia Irruan, Boki in Cross River State, Nigeria on the $25^{\text {th }}$ April 1967. As a youth, he had a good village experience in farming with his parents especially tree crops and some arable crops during his Primary and Secondary school days. He subsequently trained as Soil Scientist at the University of Agriculture, Makurdi, Benue State, Nigeria between 2006 and 2012 where he obtained M.Sc. and Ph. D in Soil Fertility and Plant Nutrition.

$\mathrm{He}$ was an Instructor at the defunct Ibrahim Babangida College of Agriculture, Obubra in Cross River State between 1997 and 2002. A Field Technologist in the Department of Agronomy, Cross River University of Technology, Calabar (Obubra Campus), 2002 - 2008. Became a full time Lecturer in same Department 2008 to date. He is currently a Senior Lecturer and Acting Head of Department of Agronomy, Cross River University of Technology Calabar (Obubra Campus).

Dr Kekong is a member of Soil Science Society of Nigeria (SSSN) and a member of International Union of Soil Science (IUSS).

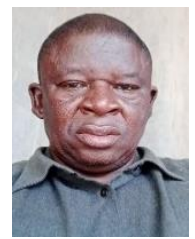

Utietiang Litio Undie was born in Obudu, Cross River State Nigeria on the $26^{\text {th }}$ December 1959. He attended both Primary and Secondary schools at Obudu. He subsequently trained as Agricultural Scientist both at the University of Calabar, Nigeria for B.Sc. in Plant Ecology in 1980; M.Sc. in Crop Physiology University of Maiduguri, Borno State, Nigeria in 1989 and Ph.D Crop Production, University of Calabar, Nigeria in 2012.

He taught Crop Science at the College of Education, Akamkpa Cross River State between 1990 - 2002. Lecturer, Cross River University of Technology Obubra Campus 2002 - date. He is currently a Senior Lecturer and an Adjunct Professor in Crop Production at the University of Calabar, Nigeria.

Dr Undie is a member of the Crop Science Society of Nigeria and a member of Nigeria Agricultural Society. 